\title{
Dry matter yield and nutritional value of Marandu grass under nitrogen fertilization and irrigation in cerrado in São Paulo ${ }^{1}$
}

\author{
Elisângela Dupas ${ }^{2}$, Salatiér Buzetti ${ }^{2}$, André Luis Sarto², Fernando Braz Tangerino \\ Hernandez $^{2}$, Antonio Fernando Bergamaschine ${ }^{2}$
}

\author{
1 Projeto financiado pela FAPESP. \\ 2 Departamento de Fitossanidade, Engenharia Rural e Solos; Departamento de Zootecnia e Biologia - FEIS/UNESP, Passeio: Monção, 226, \\ Caixa Postal 31, 15385-000, Ilha Solteira/SP.
}

\begin{abstract}
The aim of this study was to evaluate dry matter yield and nutritional value of palisade grass (Brachiaria brizantha cv. Marandu) using nitrogen doses and sprinkler irrigation in two periods of the year, aiming at reducing seasonality of forage production. It was used a randomized block design in a split-plot scheme, with five doses of nitrogen (0, 50, 100, 150 , and $200 \mathrm{~kg} / \mathrm{ha} / \mathrm{cut}$ ), and the sub-plots were defined by the seasons of the year (wet and dry season), with and without irrigation. During the wet season, in the plots with and without irrigation, doses of 175 and $161 \mathrm{~kg} / \mathrm{ha} / \mathrm{cut}$ promoted the highest dry matter yields. During the dry season, $171 \mathrm{~kg} \mathrm{ha}^{-1} \mathrm{~N}$ with irrigation resulted in the highest dry matter yield. During the same season, there was no response to $\mathrm{N}$ fertilization in the lack of irrigation. Average contents of CP were $10 \%$ with and without irrigation. Contents of neutral detergent fiber decreased with nitrogen doses, while acid detergent fiber was not affected by fertilization. Plots under irrigation reached the maximal acid detergent fiber content at $\mathrm{N}$ dose of $60 \mathrm{~kg}^{-1}$. Irrigation promotes increase of $15 \%$ increase in dry matter yield and it increases contents of neutral detergent fiber.
\end{abstract}

Key Words: Brachiaria brizantha, nitrogen, pasture

\section{Produtividade de matéria seca e valor nutritivo do capim-marandu sob adubação nitrogenada e irrigação no cerrado paulista}

RESUMO - Objetivou-se com este trabalho avaliar a produtividade de matéria seca e valor nutritivo do capim-marandu (Brachiaria brizantha, cv. Marandu) utilizando doses de nitrogênio e irrigação por aspersão em dois períodos do ano, visando à redução da estacionalidade de produção de forragem. O delineamento experimental foi de blocos ao acaso em esquema de parcelas subdivididas com cinco doses de nitrogênio (0,50,100, 150 e $200 \mathrm{~kg} / \mathrm{ha} / \mathrm{corte})$ e as subparcelas definidas pelos períodos do ano (período das águas e da seca), com e sem irrigação. No período das águas, nas parcelas com e sem irrigação, as doses de 175 e $161 \mathrm{~kg} / \mathrm{ha}$ /corte promoveram as máximas produções de MS. No período da seca, a dose $171 \mathrm{~kg} \mathrm{ha}^{-1}$ de $\mathrm{N}_{\text {com irrigação }}$ propiciou a máxima produtividade de MS. No mesmo período, na ausência de irrigação, não houve resposta à adubação nitrogenada. Os teores médios de PB foram de 10\%, com e sem irrigação. Os teores de FDN decresceram com as doses de nitrogênio, enquanto os de FDA não foram influenciados pela adubação. As parcelas sob irrigação atingiram o máximo teor de FDA com a dose de nitrogênio de $60 \mathrm{~kg} \mathrm{ha}^{-1}$. A irrigação promove aumento de $15 \%$ na produtividade de matéria seca e aumenta os teores de fibra em detergente neutro.

Palavras-chave: Brachiaria brizantha, nitrogênio, pastagem

\section{Introduction}

Brazil has the largest commercial cattle herd in the world and it is the largest beef exporter in the world. This has led to the need to increase Brazilian forage production potential, since its agricultural system mostly consists of free-range breeding and pasture grazing is the cheapest way to feed cattle. Therefore, for the intensive use of pastureland, nitrogen fertilization and irrigation are among the most important factors that can determine the yield and quality of pastures.

Nitrogen, among all the nutrients, is quantitatively the most important for the growth of grass-established pastures (Monteiro et al., 2004), and the second most limiting factor for the development of forage plants (Jarvis et al., 1995).

Nitrogen is a constituent of the proteins that participate actively in the synthesis of the organic compounds that comprise the vegetable structure, and it is responsible for 
size-related characteristics of the plants such as size of leaves and stem, and shoot emergence and development (Werner, 1986).

The main objective of establishing irrigated pastures is to reduce the seasonality of forage production in the dry season of the year, provided luminosity and temperature are not limiting (Ribeiro et al., 2009). Even during the rainy season, correcting water deficiency in the summer periods may increase forage production substantially, suggesting that there is a potential for the use of a year-round pasture irrigation when the conditions of soil fertility and temperature and the photoperiod during winter are not limiting (Maya, 2003). According to Corsi \& Martha Jr. (1998), water scarcity in the dry season limits leaf expansion rate, number of leaves per shoot, and number of shoots.

The purpose of this work was to evaluate the dry weight yield and nutritional value of Marandu grass using nitrogen doses and sprinkler irrigation in two seasons of the year (the wet and dry seasons).

\section{Material and Methods}

The experiments were carried out in an area previously occupied by Panicum maximum cv. Colonião pasture with total rainfall, total irrigation, average and minimum temperature, average global radiation and average net radiation for the 10 cuts shown in the Figure 1.
The soil in the area was classified as eutrophic Red Argisol with a sandy texture (EMBRAPA, 1999). Analyses were performed on cuts from December 2005, March 2006 and July 2006 (Table 1). In February 2006, $81 \mathrm{~kg} \mathrm{ha}^{-1}$ of $\mathrm{P}_{2} \mathrm{O}_{5}$ in the form of simple superphosphate and $96 \mathrm{~kg} \mathrm{ha}^{-1}$ of $\mathrm{K}_{2} \mathrm{O}$ in the form of potassium chloride $(\mathrm{KCl})$ were applied. In April 2006, $71 \mathrm{~kg} \mathrm{ha}^{-1}$ of $\mathrm{P}_{2} \mathrm{O}_{5}$ (SS) and $130 \mathrm{~kg} \mathrm{ha}^{-1}$ of $\mathrm{K}_{2} \mathrm{O}$ (KCl) were applied; and in August 2006, $56 \mathrm{~kg} \mathrm{ha}^{-1}$ of $\mathrm{P}_{2} \mathrm{O}_{5}$ (SS) and $139 \mathrm{~kg} \mathrm{ha}^{-1}$ of $\mathrm{K}_{2} \mathrm{O}(\mathrm{KCl})$ were applied to adjust the phosphorus and potassium contents to $30 \mathrm{mg} \mathrm{dm}^{-3}$ and $5 \%$ of the cation exchange capacity occupied by potassium.

The areas were ploughed, then harrowed twice and sown with Marandu grass on April $28^{\text {th }} 2005$. In the irrigated experiment, the irrigation system was a conventional fixed sprinkling, $12 \times 12 \mathrm{~m}$ sprinkler spacing, average precipitation of $7.0 \mathrm{~mm} \mathrm{~h}^{-1}$ and a mean Christiansen uniformity coefficient (CUC) of 84.5\%. A fixed sprinkling design of three days was adopted, with replacement of reference evapotranspiration estimated by PenmanMonteith (Allen et al., 1998) and a crop coefficient of 1.0.

Five nitrogen doses $(0,50,100,150$, and $200 \mathrm{~kg} / \mathrm{ha} / \mathrm{cut})$ were applied in the form of urea ( $45 \%$ of $\mathrm{N})$, totaling 0,300 , 600,900 and $1200 \mathrm{~kg} \mathrm{ha}^{-1}$ in the wet season and 0, 200, 400, 600 and $800 \mathrm{~kg} \mathrm{ha}^{-1}$ in the dry season. The experimental design adopted was randomized blocks in a split-plot scheme for the variables under study, in which the plots were represented by the nitrogen doses and the split-plots by the

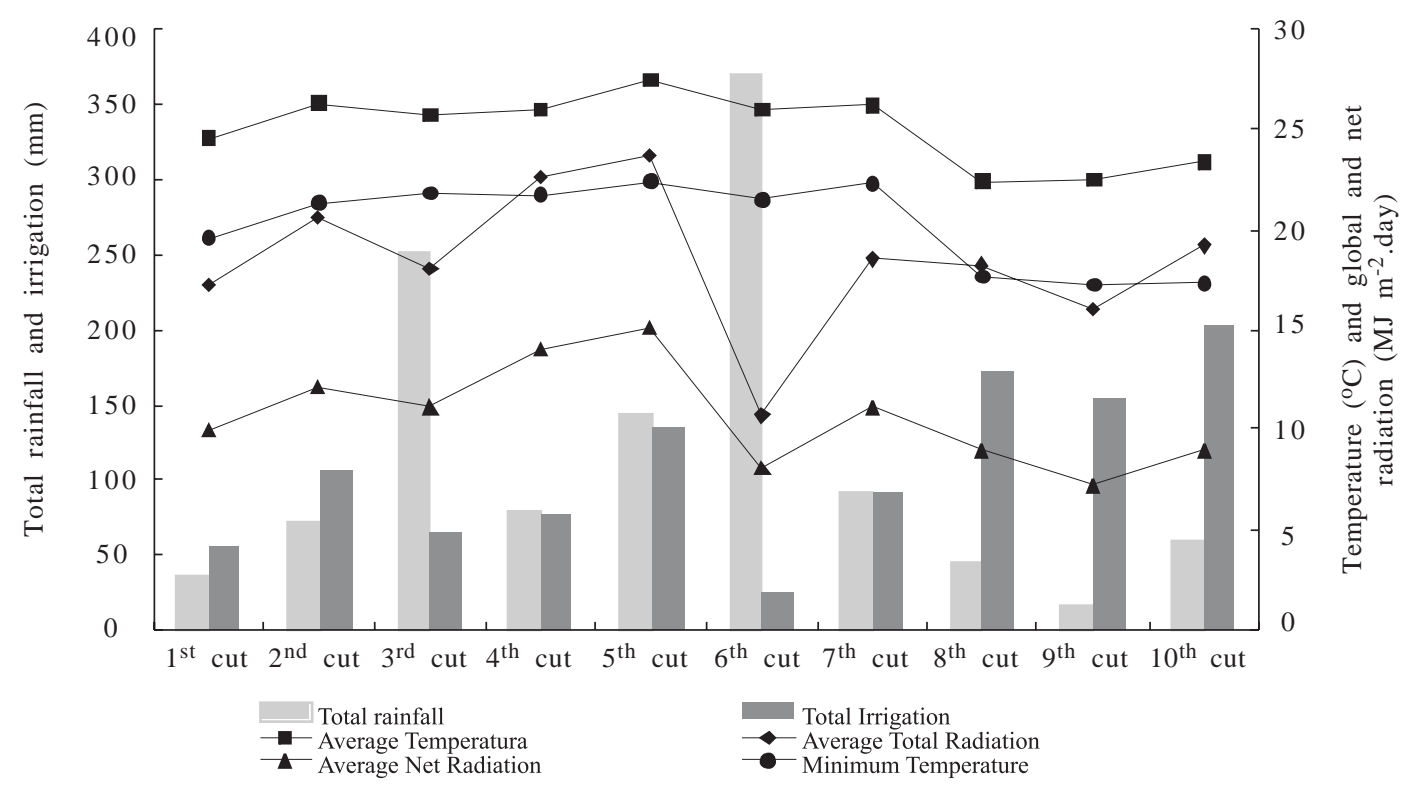

$1^{\text {st }}$ cut - October $15^{\text {th }} 2005 ; 2^{\text {nd }}$ cut - November $15^{\text {th }} 2005 ; 3^{\text {rd }}$ cut - December $15^{\text {th }} 2005 ; 4^{\text {th }}$ cut - January $12^{\text {th }} 2006$; $5^{\text {th }}$ cut February $10^{\text {th }} 2006 ; 6^{\text {th }}$ cut - March $12^{\text {th }} 2006 ; 7^{\text {th }}$ cut - April $9^{\text {th }} 2006 ; 8^{\text {th }}$ cut - May $24^{\text {th }} 2006 ; 9^{\text {th }}$ cut - July $13^{\text {th }} 2006$ and the $10^{\text {th }}$ cut - September $5^{\text {th }} 2006$

Figure 1 - Total rainfall, total irrigation (mm), average and minimum temperature, average global radiation and average net radiation for the 10 cuts of Marandu grass (Ilha Solteira, SP, 2005/2006). 
Table 1 - Results of the soil chemical analyses of the experimental areas in the 0 to $20 \mathrm{~cm}$ layer

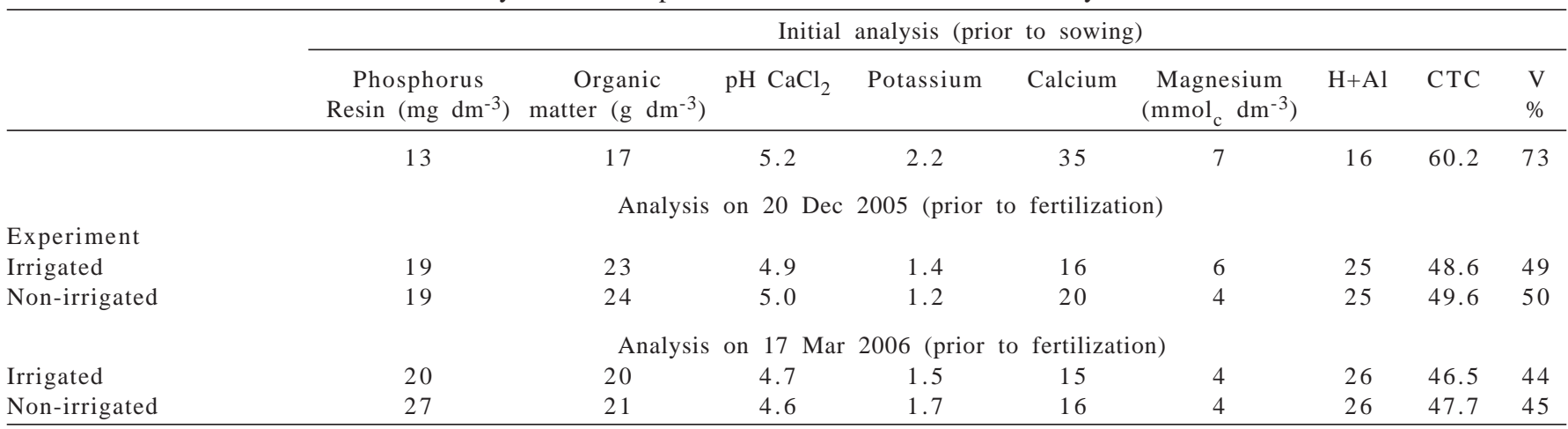

seasons of the year (wet and dry seasons). Each plot in each experiment comprised a $9.0 \mathrm{~m}^{2}$ area $(3 \times 3 \mathrm{~m})$, with $2 \mathrm{~m}$ spacing between them.

For establishment of Marandu grass, fertility of the soil was corrected by applying $20 \mathrm{~kg} \mathrm{ha}^{-1}$ of nitrogen. Phosphorus (P) and potassium (K) were based on theoretical doses to reach $\mathrm{P}$ values of $30 \mathrm{mg} \mathrm{dm}^{-3}$ and, for $\mathrm{K}, 5 \%$ of the cation exchange capacity (Bear \& Prince, 1945; Bear \& Toth, 1948). For every three-cut interval, $18 \mathrm{~kg} \mathrm{ha}^{-1}$ of $\mathrm{K}_{2} \mathrm{O}(\mathrm{KCl})$ were applied and a new chemical analysis of the soil was performed to readjust the phosphorus and potassium contents to $30 \mathrm{mg} \mathrm{dm}^{-3}$ of $\mathrm{P}$ and $5 \%$ of the cation exchange capacity occupied by potassium. The purpose of this treatment was to ensure that the plants were well nourished with phosphorus and potassium, thus showing their best response to nitrogen. It was applied $20 \mathrm{~kg}$ of $\mathrm{N}$ on August $19^{\text {th }} 2005$ and reaplication on August $22^{\text {nd }} 2005$. On September $5^{\text {th }} 2005$, the first low cut was carried out and fertilization with the $\mathrm{N}$ doses was started on the plots.

Sample collections began on October $15^{\text {th }} 2005$, when the first cut was carried out on both experiments. The subsequent cuts were performed at 28 to 32 days intervals in the wet season (six cuts) and 40 to 45 days in the dry season (four cuts). The cuts in the wet season were performed on October $15^{\text {th }} 2005$, November $15^{\text {th }} 2005$, December $15^{\text {th }} 2005$, January $12^{\text {th }} 2006$, February $10^{\text {th }}$ 2006 and March $12^{\text {th }}$ 2006, respectively and in the dry season the cuts were performed on April $9^{\text {th }}$ 2006, June $24^{\text {th }} 2006$, July $13^{\text {th }} 2006$ and on September $5^{\text {th }} 2006$, respectively.

Cutting was manually performed at $15 \mathrm{~cm}$ from the ground, in the middle of the plots, in a $1.0 \mathrm{~m}^{2}$ delimited area. The cut forage was packaged in plastic bags and weighed. Subsequently, a representative sample of approximately $800 \mathrm{~g}$ was removed for drying. The remainder of the grass on the plots was cut (scythed) with a mechanical scythe and removed from the plots. Nitrogen was then applied by scattering on each plot. The samples were stored in paper bags and oven dried at $65^{\circ} \mathrm{C}$ for 72 hours (Silva \& Queiroz, 2002). After that, they were weighed and ground in a Wiley-type mill equipped with a $1 \mathrm{~mm}$ mesh sieve.

The dry weight yield was calculated by multiplying the quantity of green matter $\left(\mathrm{kg} \mathrm{m}^{-2}\right)$ by the original dry weight content. Contents of dry weight $\left(105^{\circ} \mathrm{C}\right)$, crude protein (CP), neutral detergent fiber (NDF) and acid detergent fiber (ADF) were determined according to the methodology described by Silva \& Queiroz (2002).

The data were subjected to an analysis of variance (F test) and a joint analysis for irrigation, as well as a regression analysis of the nitrogen doses. The statistical analyses were performed with SANEST - Statistical Analysis System software (Zonta \& Machado, 1987).

\section{Results and Discussion}

Dry weight (DW) yield of Marandu grass in the irrigated experiment indicated that the effect of the interaction between nitrogen doses $\times$ cutting periods was significant. In the wet season, the dry weight yield was fitted to the quadratic equation regarded to nitrogen doses, with maximum DW yield of 24.9 tha $^{-1}$ and an average of $4.1 \mathrm{t} / \mathrm{ha} /$ cut obtained with a nitrogen dose of $1.064 \mathrm{~kg} \mathrm{ha}^{-1}$ (Figure 2a).

For the dry season, the dry weight yield was also fitted to the quadratic equation with maximal DM yield at $10.5 \mathrm{t} \mathrm{ha}^{-1}$ and an average of $2.6 \mathrm{t} / \mathrm{ha} /$ cut with a nitrogen dose of $686.7 \mathrm{~kg} \mathrm{ha}^{-1}$ (Figure 2b). The average DM yields of Marandu grass in the irrigated experiment were $3.2 \mathrm{t} / \mathrm{ha} / \mathrm{cut}$ and $2.0 \mathrm{t} / \mathrm{ha} / \mathrm{cut}$ in the wet and dry seasons, respectively.

In the non-irrigated experiment, the DM yield in the wet season was fitted to the quadratic equation with maximal DM yield at $24.2 \mathrm{t} \mathrm{ha}^{-1}$ and an average of $4 \mathrm{t} / \mathrm{ha} /$ cut with a nitrogen dose of $947 \mathrm{~kg} \mathrm{ha}^{-1}$ (Figure 2c). In the dry season, nitrogen did not affect the DM yield due to the scanty 

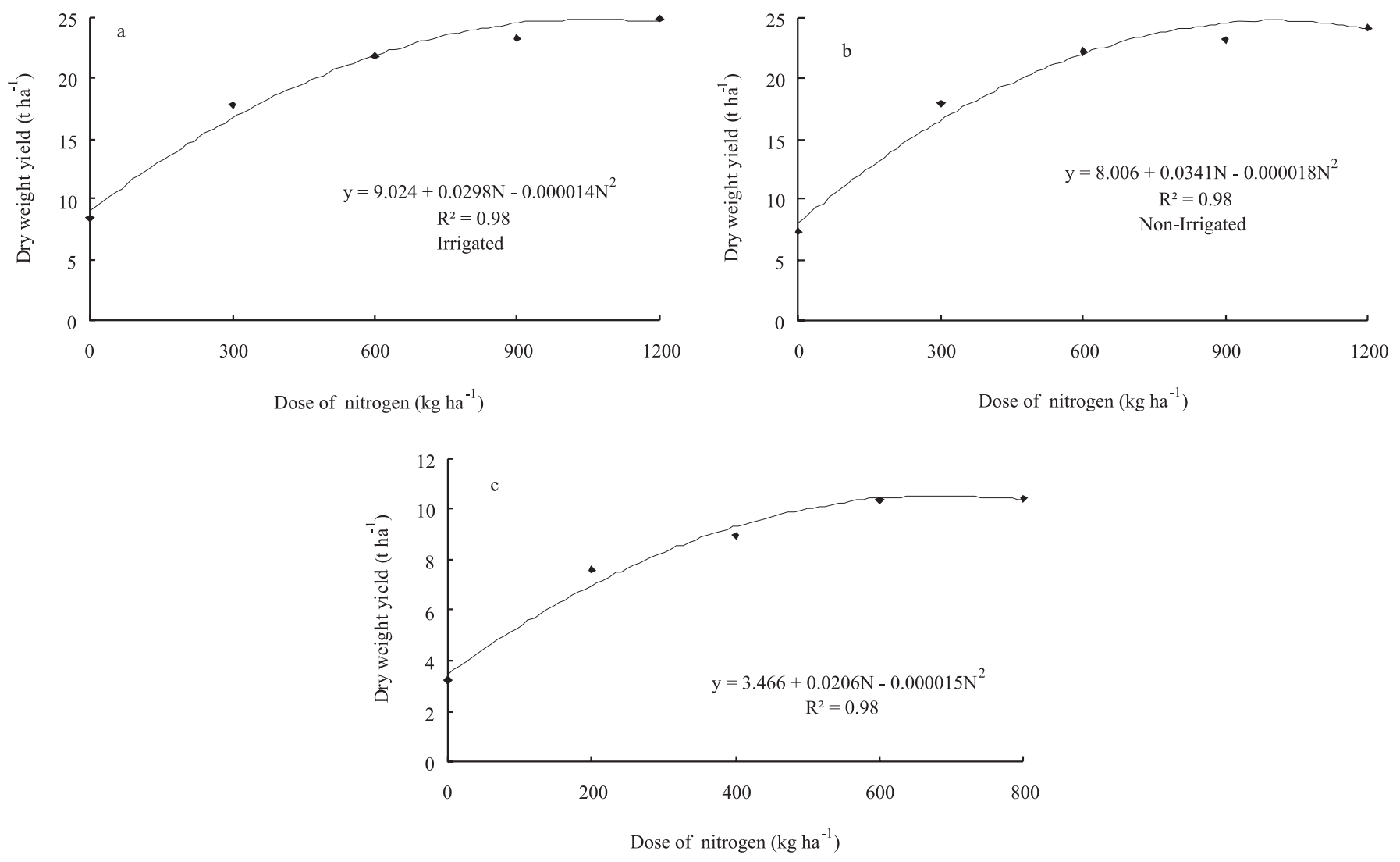

Figure 2 - Dry weight yield in the irrigated experiment (a) and the non-irrigated experiment (b) in the wet season (sum of six cuts) and in the non-irrigated experiment in the dry season (c) (sum of four cuts).

rainfall, which, allied to the low temperature and photoperiod, limited the production potential of Marandu grass.

The average DW yields in the wet and dry seasons were $3.2 \mathrm{t} / \mathrm{ha} /$ cut and $1.1 \mathrm{t} / \mathrm{ha} / \mathrm{cut}$, respectively. In the dry season, $65 \%$ less dry weight was produced than in the wet season.

According to EMBRAPA (2007), Marandu grass presents an annual DW yield in the order of $8.0 \mathrm{tha}^{-1}$, which may reach up to $20.0 \mathrm{t} \mathrm{ha}^{-1}$ through the application of fertilizers in general. It was found that the use of nitrogen fertilization and irrigation resulted in an average production of $19.3 \mathrm{tha}^{-1}$ and $8.1 \mathrm{t} \mathrm{ha}^{-1}$ in the wet and dry seasons, respectively. Using only fertilization resulted in the production of $19 \mathrm{t} \mathrm{ha}^{-1}$ and $4.4 \mathrm{t} \mathrm{ha}^{-1}$ in the wet and dry seasons, respectively.

The average CP content of Marandu grass in the irrigated experiment revealed a significant effect for the seasons of the year $\times$ doses of $\mathrm{N}$, with higher contents in the wet season (11.4\%) than in the dry season (10.4\%). Euclides (1995) reported higher percentages of CP in both leaves and stems of Marandu grass and Tanzania grass in the wet season. Contents of crude protein were fitted to the quadratic equation with maximal content at $13.4 \%$, which was obtained with a nitrogen dose of $357.0 \mathrm{~kg} / \mathrm{ha} / \mathrm{cut}$, extrapolating the maximal applied dose. In the non-irrigated experiment, the $\mathrm{N}$ doses influenced the mean $\mathrm{CP}$ contents. In this case, the quadratic equation was fitted to the maximal content of $12.8 \%$ obtained with a dose of $244.0 \mathrm{~kg} / \mathrm{ha} / \mathrm{cut}$, extrapolating the maximal applied dose (Figure 3a).

According to Van Soest (1994), forage with a CP content lower than $7 \%$ reduces its digestion due to the inadequate quantities of nitrogen for the microorganisms in the rumen, diminishing their population, and thus reducing the digestibility and ingestion of dry weight. In this work, the average CP contents were higher than $10 \%$. According to data published by EMBRAPA (2007), CP contents in samples of simulated animal forage in the wet and dry seasons were, respectively, $9.3 \%$ and $6.2 \%$.

The average NDF contents showed significant differences according to the seasons of the year in the irrigated experiment and to the doses of $\mathrm{N}$ in both the irrigated and non-irrigated experiments. An analysis of the effect of the season of the year on the NDF contents in the irrigated experiment indicated that higher values (65.4\%) were recorded in the dry season than in the wet season (63.8\%) due to the higher DW yield, which resulted in higher $\mathrm{CP}$ and lower NDF contents. 


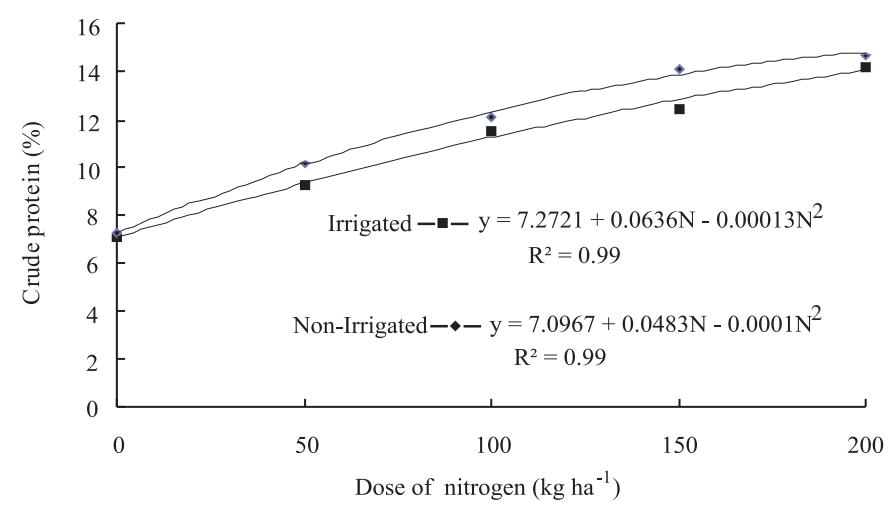

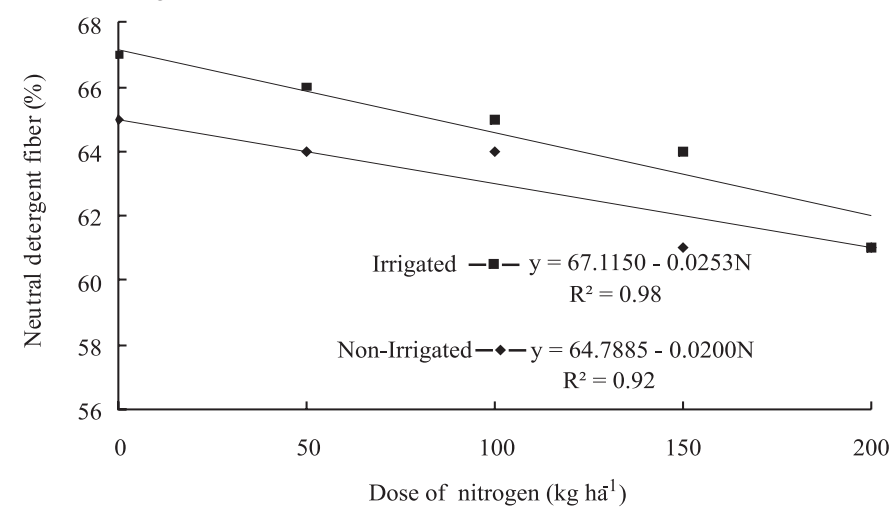

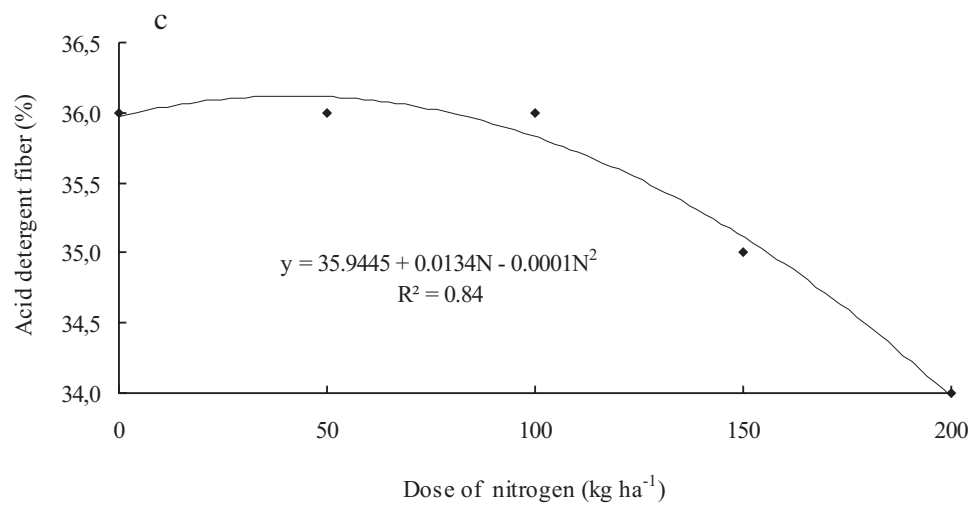

Figure 3 - Average contents of crude protein (a), neutral detergent fiber (b) and acid detergent fiber (c) in Marandu grass in the irrigated and non-irrigated experiments.

Content of neutral detergent fiber in the nitrogen doses (Figure 3b) showed a decreasing linear behavior according to the increment in the doses applied on the pasture. These results are similar to those reported by Costa et al. (2007), who evaluated the effect of nitrogen doses on the bromatological composition of Marandu grass in a moderate state of degradation, and observed a reduction in NDF contents with increasing doses of $\mathrm{N}$, with the results adjusted to linear regression. The average values fitted by the regression equation ranged from 70.4 to $64.2 \%$, respectively, for the control treatment and the maximal dose under study in the three evaluated years. The lowest NDF content was obtained with a nitrogen dose of $300 \mathrm{~kg} \mathrm{ha}^{-1}$, showing an $8.93 \%$ reduction in relation to the control. According to Dias et al. (2000), higher doses of $\mathrm{N}$ applied in a given period, depending on the environmental conditions, may alter the NDF content. Similar results were reported by Marcelino et al. (2002), who found a reduction in the NDF content with increasing doses of N. According to Corsi (1984), nitrogen fertilization may reduce the percentage of NDF in plants by stimulating the growth of new tissues, whose dry matter contains lower contents of structural carbohydrates.

Burton (1998) explained that fertilization, especially with nitrogen, increases not only the DW yield but also the
$\mathrm{CP}$ concentration of forage, and in some cases, it reduces the fiber content, which contributes to improve its nutritional value.

In the present work, it was found average NDF contents of 62 to $65 \%$, which could hinder the consumption of Marandu grass. Content of neutral detergent fiber is the most limiting factor in the consumption of roughage fodder, and contents of cell wall constituents exceeding 55 to $60 \%$ in dry matter are negatively correlated with forage consumption (Van Soest, 1994). Therefore, the concentration of NDF is the forage component most consistently associated with consumption.

The ADF contents were significant in the cutting periods of the irrigated experiment, in which higher contents were found in the dry season (37.8\%) in comparison to the wet season (35.6\%). The doses of $\mathrm{N}$ in the non-irrigated experiment were fitted to the quadratic equation with the maximum ADF content (36.35\%) found at a $\mathrm{N}$ dose of $60 \mathrm{~kg} / \mathrm{ha} / \mathrm{cut}$ (Figure 3c). The ADF contents were, on average, lower than $40 \%$. Nussio et al. (1998) reported that forage with ADF values around $40 \%$ or higher have a low consumption potential and lower digestibility.

A joint analysis of the experiments was performed to ascertain the effect of irrigation on the DM yield and on 
contents of CP, NDF and ADF. The results of the DW yield and NDF contents were influenced by irrigation. On average, the DW yield in the two periods under evaluation was higher in the irrigated experiment $\left(1.4 \mathrm{tha}^{-1}\right)$ than in the nonirrigated treatment $\left(1.2 \mathrm{tha}^{-1}\right)$. Therefore, the use of irrigation may increase the DW yield of Marandu grass by $15 \%$. Higher NDF contents were obtained with irrigation (64.6\%) than without irrigation (62.8\%), which may be attributed to the effect of nitrogen dilution caused by cell wall expansion resulting from the higher growth rate of the plants in the warm season of the year (Lopes et al., 2005).

In the wet season, the average DW yield of Marandu grass was $1.9 \mathrm{t} \mathrm{ha}^{-1}$ in the irrigated experiment and $1.8 \mathrm{t} \mathrm{ha}^{-1}$ in the non-irrigated experiment, i.e., with no statistically significant difference. In the dry season, the average yields were $8.1 \mathrm{t} \mathrm{ha}^{-1}$ in the irrigated treatment and $4.4 \mathrm{tha}^{-1}$ in the non-irrigated treatment. The irrigated experiment produced 55\% more than the non-irrigated one. Moreover, Corsi (1998) stated that irrigation can be employed during the dry season in the states of São Paulo, Minas Gerais and Mato Grosso do Sul, and emphasized that the DW yield of grass is half of the yield obtained in summer.

\section{Conclusions}

Considering the yield of dry mass and its nutritional value, a nitrogen dose of $170 \mathrm{~kg} / \mathrm{ha} / \mathrm{cut}$ is recommended, regardless to the season of the year, as well as irrigation in the dry season. The use of irrigation increases the dry weight yield and the neutral detergent fiber content. Crude protein and acid detergent fiber contents are not influenced by irrigation.

\section{References}

ALlen, R.G; PEREIRA, L.S; RAES, D. et al. Crop evapotranspiration-guidelines for computing crop water requirements. Rome: FAO Irrigation and Drainage, 1998. 56p.

BEAR, F.E.; PRINCE, A.L. Cation-equivalent constancy in alfalfa. Journal of American Society of Agronomy, v.37, p.217-222, 1945.

BEAR, F.E.; TOTH, S.J. Influence of calcium on availability of other cations. Soil Science, v.65, p.67-74, 1948.

BURTON, G.W. Registration of Tifton 78 Bermuda grass. Crop Science, v.28, p.187-188, 1998.

CORSI, M. Effects of nitrogen rates and harvesting intervals on dry matter production, tillering and quality of the tropical grass Panicum maximum, JACQ. 1984. 125f. Thesis (Doctor of Philosophy) - The Ohio State University, Ohio.

CORSI, M. Dica de especialista: melhor resposta no verão. DBO Rural, v.17, n.218, p.62, 1998.
CORSI, M.; MARTHA JR, G.B. Manejo de pastagens para produção de carne e leite. In: SIMPÓSIO SOBRE MANEJO DE PASTAGENS, 15., 1998, Piracicaba. Anais... Piracicaba: Fundação de Estudos Agrários Luiz de Queiroz, 1998. p.55-84.

COSTA, K.A.P.; FAQUIN, V.; OLIVEIRA, I.P. et al. Doses e fontes de nitrogênio na compoisção bromatológica de Brachiaria brizantha cv. Marandu em estágio moderado de degradação. In REUNIÃO ANUAL DA SOCIEDADE BRASILEIRA DA SOCIEDADE BRASILEIRA DE ZOOTECNIA, 44., 2007, Jaboticabal. Resumos... Jaboticabal: SBZ, UNESP, 2007.

DIAS, P.F.; ROCHA, G.P.; ROCHA FILHO, R.R. et al. Produção e valor nutritivo de gramíneas forrageiras tropicais, avaliadas no período das águas, sob diferentes doses de nitrogênio. Ciência e Agrotecnologia, v.24, n.1, p.260-271, 2000.

EMPRESA BRASILEIRA DE PESQUISA AGROPECUÁRIA EMBRAPA. Sistema brasileiro de classificação de solos. Brasília: Embrapa Solos, 1999. 412p.

EMPRESA BRASILEIRA DE PESQUISA AGROPECUÁRIA EMBRAPA. Marandu: cultivar de Brachiaria brizantha. Campo Grande: Embrapa Gado de Corte, 2007. 2p. Disponível em: <http:// www.cnpgc.embrapa.br/produtoseservicos/pdf/marandu.pdf $>$. Acesso em: 27/5/2007.

EUCLIDES, V.P.B. Valor alimentício de espécies forrageiras do gênero Panicum. In: SIMPÓSIO SOBRE MANEJO DA PASTAGEM, 12., 1995, Piracicaba. Anais... Piracicaba: FEALQ, 1995. p.245-273.

JARVIS, S.; SCHOLEFIELD, D.; PAIN, B. Nitrogen cycling in grazing systems. In: BACON, P.E. (Ed.). Nitrogen fertilization in the environment. New York: M. Dekker, 1995. p.381-420.

LOPES, R.S.; FONSECA, D.M.; OLIVEIRA, R.A. et al. Efeito da irrigação na disponibilidade e composição bromatológica da massa seca de lâminas foliares de capim-elefante. Revista Brasileira de Zootecnia, v.34, n.1, p.20-29, 2005.

MARCELINO, K.R.A.; LEITE, G.G.; VILELA, L. et al. Influência de nitrogênio e tensões hídricas sobre o valor nutritivo de marandu (Brachiaria brizantha) cultivado no cerrado. In: REUNIÃO ANUAL DA SOCIEDADE BRASILEIRA DE ZOOTECNIA, 39., 2002, Recife. Anais... Recife: Sociedade Brasileira de Zootecnia, 2002. (CD-ROM).

MAYA, F.L.A. Produtividade e viabilidade econômica da recria e engorda de bovinos em pastagens adubadas intensivamente com e sem uso da irrigação. 2003. 81f. Dissertação (Mestrado em Ciência Animal e Pastagem) - Escola Superior de Agricultura “Luiz de Queiroz”, Universidade de São Paulo, Piracicaba.

MONTEIRO, F.A.; COLOZZA, M.T.; WERNER, J.C. Enxofre e micronutrientes em pastagens. In: SIMPÓSIO SOBRE MANEJO DE PASTAGEM, 21., 2004, Piracicaba. Anais... Piracicaba: FEALQ, 2004. p.279-301.

NUSSIO, L.G.; MANZANO, R.P.; PEDREIRA, C.G.S. Valor alimentício em plantas do gênero Cynodon. In: SIMPÓSIO SOBRE MANEJO De PASTAGEM, 15., 1998, Piracicaba. Anais... Piracicaba: FEALQ/ESALQ, 1998. p.203-242.

RIBEIRO, E.G.; FONTE, C.A.A.; PALIERAQUI, J.G.B. et al. Influência da irrigação nas épocas seca e chuvosa, na produção e composição química dos capins napier e mombaça em sistema de lotação intermitente. Revista Brasileira de Zootecnia, v.38, n.8, p.1432-1442, 2009.

SILVA, D.J.; QUEIROZ, A.C. Análise de alimentos: métodos químicos e biológicos. 3.ed. Viçosa, MG: UFV, 2002. 235p.

VAN SOEST, P.J. Nutritional ecology of the ruminant. New York: Cornell University Press, 1994. 476p.

WERNER, J.C. Adubação de pastagens. Nova Odessa: Instituto de Zootecnia, 1986. 49p.

ZONTA, E.P.; MACHADO, A.A. SANEST - Sistema de análise estatística para microcomputadores. Pelotas: DMEC/IFM/ UFPel, 1987. 138p. 